\title{
Genetic Control of VEGF and TGF- $\beta 1$ Gene Polymorphisms in Childhood Urinary Tract Infection and Vesicoureteral Reflux
}

\author{
HYUNG EUN YIM, IN SUN BAE, KEE HWAN YOO, YOUNG SOOK HONG, AND JOO WON LEE \\ Department of Pediatrics, College of Medicine, Korea University, Seoul, 152-703, Korea
}

\begin{abstract}
We investigated whether genetic polymorphisms of vascular endothelial growth factor (VEGF) and transforming growth factor- $\beta 1$ (TGF- $\beta 1$ ), potential candidate genes in the pathogenesis of urinary tract infection (UTI) and vesicoureteral reflux (VUR), are associated with the susceptibility to UTI and VUR, and renal scarring. We recruited 89 controls and 86 UTI and 58 VUR children. The UTI group was subdivided into two groups according to renal scarring. Two polymorphisms of VEGF and three of TGF- $\beta 1$ genes were investigated by using PCR-restriction fragment length polymorphism analysis. In both UTI and VUR groups, there was an increase in frequency of the VEGF - $460 \mathrm{CC}$ (control, 4.3; UTI, 15.9; VUR, $17.8 \%$; $p<0.05$ ), TGF- $\beta 1-509$ CC (control, 8.7; UTI, 34.6; VUR, $35.1 \% ; p<0.001$ ), and TGF- $\beta 1-800 \mathrm{GG}$ genotypes (control, 19.1; UTI, 40.5; VUR, 40.4\%; $p<0.05$ ). An increase in the TGF- $\beta 1+869$ CC (scar-positive, 35.4; scar-negative, 10.3\%; $p<0.05$ ) and a decrease in the +869 TC genotype (scar-positive, 29.2; scarnegative, 55.2\%; $p<0.05$ ) were observed in the scar-positive subjects. There were no differences in +405 VEGF genotype frequencies. The VEGF T-460C and the TGF- $\beta 1$ C-509T, G-800A, and T869C polymorphisms could be genetic markers of the process of UTI and VUR. (Pediatr Res 62: 183-187, 2007)
\end{abstract}

$\mathrm{U}$ TI and VUR are common childhood problems, leading to renal scars and increasing the risk of renal insufficiency and hypertension. Knowledge of the effects of cytokine regulation on the process of UTI has recently improved $(1,2)$ and insights into the pathogenesis, genesis, and outcome of VUR and renal scarring also have been made (3). Many in vitro studies have shown that the expression of individual cytokines or cytokine receptors is influenced by polymorphic genotypes within regulatory regions, and that these polymorphic genotypes may play pivotal roles in the pathogenesis and progression of chronic renal diseases (4). We also recently reported the associations of genetic polymorphisms of the reninangiotensin system, which are known to affect renal pathophysiology and primary VUR (5).

Among various proteins, vascular endothelial growth factor (VEGF) and transforming growth factor- $\beta 1$ (TGF- $\beta 1$ ) have been implicated as potential candidate genes in the pathomechanisms of numerous renal diseases. VEGF, also known as vascular permeability factor, is a potent mitogen that enhances the proliferation of vascular endothelial cells, angio-

Received November 2, 2006; accepted March 15, 2007

Correspondence: Kee Hwan Yoo, M.D., PhD., Department of Pediatrics, Guro Hospital, Korea University Medical Center, \#80, Guro-Dong, Guro-Gu, Seoul, 152-703, Korea; e-mail: guroped@korea.ac.kr

Supported in part by a Korea University research grant. genesis, and microvascular permeability (6). In the kidney, VEGF is expressed in glomerular podocytes, as well as epithelial cells of distal tubules and collecting ducts. VEGF expression is enhanced in mesangial proliferative disease, chronic tubulointerstitial injury, membranous nephropathy, and diabetic nephropathy (7). Neovascularization in scarred kidneys and significant increase of urinary VEGF accompanying increased severity of renal scarring have been also reported $(8,9)$.

TGF- $\beta 1$ appears to be a key cytokine that initiates and terminates tissue repair. It is a multifunctional cytokine involved in the regulation of cell proliferation, differentiation, extracellular matrix formation, and immune response (10). Furthermore, the crucial role that this cytokine plays in the development and progression of renal injury has been well documented. Several studies suggest that TGF- $\beta 1$ is involved in the pathogenesis of congenital obstructive uropathies, acute pyelonephritis, and subsequent renal scarring $(1,11)$, and recently an in vitro VUR model shows that TGF- $\beta 1$ to be one of the key cytokines that initiates the inflammatory cascade of $\mathrm{RN}$ and functions in the chronic inflammatory phase (12).

Polymorphisms within the VEGF and TGF- $\beta 1$ genes have often been linked to overproduction of these proteins, and both predisposition to and sequelae of progressive renal disease (13-15). Several polymorphisms of the VEGF and TGF- $\beta 1$ genes have been identified, and there are reports on the association of TGF- $\beta 1$ gene polymorphism and renal scarring $(15,16)$. On the other hand, there is no published study on the link of VEGF gene polymorphism to renal scar formation, despite of the importance of hypoxia and angiogenesis in the scar formation. Therefore, the purpose of our study was to test the hypothesis that two common (T-460C and G405C) polymorphisms of the VEGF gene and three (C-509T, G-800A, and T869C) polymorphisms of the TGF- $\beta 1$ gene may be risk factors for UTI, VUR, and renal scarring.

\section{METHODS}

Study population. A total of 86 UTI patients, with a proven evidence of UTI (recognized symptoms with pure growth of $>10^{5}$ organisms $/ \mathrm{mL}$ on a catheter or suprapubic specimen of urine) were prospectively studied. Every UTI patient had a voiding cystourethrography at least $7 \mathrm{~d}$ postinfection and a total of 58 patients were diagnosed as having VUR. Patients were enrolled from the hospitalized patients of pediatric department of the Korea University Hospital when they had their first UTI. Technetium-99m dimercaptosuccinate

Abbreviations: NS, non-scarring; RN, reflux nephropathy; RPS, renal parenchymal scarring; UTI, urinary tract infection; VUR, vesicoureteral reflux 
renal scans (DMSA) were performed at the diagnosis of UTI, and again 3 mo postinfection, with the result of the last DMSA taken into consideration. The UTI group was divided into those who had RPS and those without scarring (NS) 3 mo after a proven UTI. Patients with an equivocal scan [renal hypoplasia; small kidney(s) with smooth parenchymal outlines and no focal changes], obstructive uropathy, reflux secondary to neurogenic bladder, or external malformations of the genitourinary tract were excluded. The control group consisted of 89 healthy children with no previous history of UTI or renal disease. Ethical approval for the study was granted by the Ethics Committee of the Medical College of Korea University. After informed consent for the genetic studies was obtained from the parent(s) of all subjects, blood samples were obtained for DNA analysis.

Genetic analysis. Genomic DNA was extracted from EDTA-anticoagulated blood, using a salting-out method. Specific oligonucleotide primers were designed for VEGF $(13)$ and TGF- $\beta 1(15,17,18)$ polymorphisms by using genomic sequences published previously. PCR amplification for each polymorphism was performed in a total reaction volume of $20 \mu \mathrm{L}$ with $2 \mu \mathrm{L}$ of genomic DNA, $5 \mu \mathrm{L}$ of each of primer, $250 \mu \mathrm{M}$ dNTP, $1.5 \mathrm{mM} \mathrm{MgCl}_{2}, 40$ $\mathrm{mM} \mathrm{KCl}, 10 \mathrm{mM}$ Tris- $\mathrm{HCl}$ ( $\mathrm{pH} 9.0$ ), and $1 \mathrm{U}$ TaqDNA polymerase (Bioneer, Daejeon, Korea). Thermal conditions included denaturation at $94^{\circ}$ for $5 \mathrm{~min}$, followed by 32 or 35 cycles at $94^{\circ}$ for $1 \mathrm{~min}$, annealing at $57.5-62^{\circ}$ for $30-40$ $\mathrm{s}$, and extension at $72^{\circ}$ for $1 \mathrm{~min}$, with a final extension at $72^{\circ}$ for $5 \mathrm{~min}$. All PCR reactions were performed on a thermal cycler GeneAmp PCR system 2400 (Perkin-Elmer, Boston, MA). Restriction fragment length polymorphism (RFLP) was then performed by digestion of $10 \mu \mathrm{L}$ of PCR product with 10 $\mu \mathrm{L}$ of appropriate restriction enzyme at temperatures recommended. Digested products were electrophoresed through ethidium bromide-stained 3\% agarose gels or $10 \%$ polyacrylamide gels, and detected by UV transillumination. Specific details of primer sequences, PCR conditions, and RFLP are summarized for each polymorphism in Table 1 . VEGF $-460 \mathrm{C} \rightarrow \mathrm{T}$ and TGF- $\beta 1$ $+869 \mathrm{~T} \rightarrow \mathrm{C}$ do not create or remove an enzyme restriction site; therefore, a base change was incorporated within the primer to create enzyme restriction sites.

For VEGF T-460C polymorphism, the amplified $175 \mathrm{bp}$ fragments were digested with $B s t \mathrm{UI}$ (Biolabs, Beverly, MA) and restriction products were resolved on 3\% agarose gel. Two fragments of $155 \mathrm{bp}$ and $20 \mathrm{bp}$ were present if the product was digestible. The polymorphism was characterized as CC homozygote (digestible), TT homozygote (indigestible), and TC heterozygote. For VEGF G+405C polymorphism, BsmFI (Biolabs) was used to digest the amplified $304 \mathrm{bp}$ fragments. The $\mathrm{G}$ allele was cut into $203 \mathrm{bp}$ and $101 \mathrm{bp}$ fragments, whereas the $\mathrm{C}$ allele was not digested. For TGF- $\beta 1 \mathrm{C}-509 \mathrm{~T}$ polymorphism, the amplified 808 bp fragments were digested with Bsu36I (Biolabs). Two fragments of $617 \mathrm{bp}$ and $191 \mathrm{bp}$ were shown if the product was digestible. The polymorphism was categorized as $\mathrm{CC}$ homozygote (cuttable), TT homozygote (uncuttable) and CT heterozygote. For TGF- $\beta 1$ G-800A polymorphism, the PCR products were digested with Mae III (Roche Diagnostics, Mannheim, Germany). After ethidium bromide staining, 205 bp and $183 \mathrm{bp}$ fragments appeared on the polymorphic $-800 \mathrm{G}$ allele, whereas a 388 bp fragment appeared on the $-800 \mathrm{~A}$ allele. For TGF- $\beta 1 \mathrm{~T}+869 \mathrm{C}$ polymorphism, MspA1I (Promega, Madison, WI) was used to detect the $\mathrm{T}+869 \mathrm{C}$ (Leu 10Pro) genotype and restriction products were resolved on 10\% polyacrylamide gel. The $\mathrm{T}$ allele was characterized by a $161 \mathrm{bp}$ fragment and the $\mathrm{C}$ allele by a 149 bp fragment.

Statistical analysis. Statistical analyses were performed using SigmaStat version 2.03 for Windows (Systat Software, Inc., San Jose, CA). The frequencies of the genotypes among the groups were evaluated by the $\chi^{2}$ test with $p<0.05$ considered statistically significant.

\section{RESULTS}

Study groups. The 168 subjects were genotyped for VEGF and TGF- $\beta 1$ polymorphisms. Patients with equivocal scan (3), obstructive uropathy (2), reflux secondary to neurogenic bladder (1) and external malformations of the genitourinary tract (1) were excluded. The number of UTI patients was 79 (male $54.4 \%$, female $45.6 \%$ ), which included 48 patients with RPS and 31 patients with NS, while there were 57 VUR patients (male $56.1 \%$, female $43.9 \%$ ). There were 89 control subjects (male $56.2 \%$, female $43.8 \%$ ) and the gender distribution was similar among the groups. Median age of the children in the UTI group was $3.4 \mathrm{y}$, VUR $3.2 \mathrm{y}$, and control $3.5 \mathrm{y}$. All subjects were of Korean origin. There was a higher incidence of VUR in the RPS subjects than in the NS subjects $(87.5 \%$ versus $48.4 \%, p<0.001$ ).

Genotype distribution. The distributions of genotypes and alleles for each polymorphism in patients and controls are shown in Table 2.

VEGF polymorphisms. In both UTI and VUR groups, the VEGF -460 polymorphism revealed an increase in CC genotype (control, 4.3; UTI, 15.9; VUR, 17.8\%; $p<0.05$ ) and a decrease in TC genotype (control, 41.4; UTI, 14.3; VUR, $8.9 \% ; p<0.001)$, compared with the control group. There was no significant difference in the VEGF +405 genotype frequency among the groups.

TGF-ß1 polymorphisms. Compared with the control group, the TGF- $\beta 1-509$ CC genotype was found to be significantly increased in both UTI and VUR groups (control, 8.7; UTI, 34.6; VUR, 35.1\%; $p<0.001$ ). In the UTI group, -509TT genotype was decreased compared with the control group (control, 41.3; UTI, 24.4\%; $p=0.035$ ). Also, TGF- $\beta 1$ -800 GG genotype was significantly increased in both UTI and VUR groups than in the control group (control, 19.1; UTI, 40.5; VUR, 47.4\%; $p<0.005$ ). The TGF- $\beta 1-800$ GA genotype was significantly decreased in both UTI and VUR groups (control, 80.9; UTI, 59.5; VUR, 52.6\%; $p<0.005$ ). In the TGF- $\beta 1+869$ TC polymorphism, there was no significant difference in genotype distribution among the groups. However, compared with the NS subjects in the UTI group, the RPS subjects revealed a significant increase in the $+869 \mathrm{CC}$ genotype (RPS, 35.4; NS, 10.3\%; $p=0.03$ ) and decrease in the TC genotype (RPS, 29.2; NS, 55.2\%; $p=0.043$ ).

Table 1. Details of primer sequence and reaction conditions used for RFLP typing

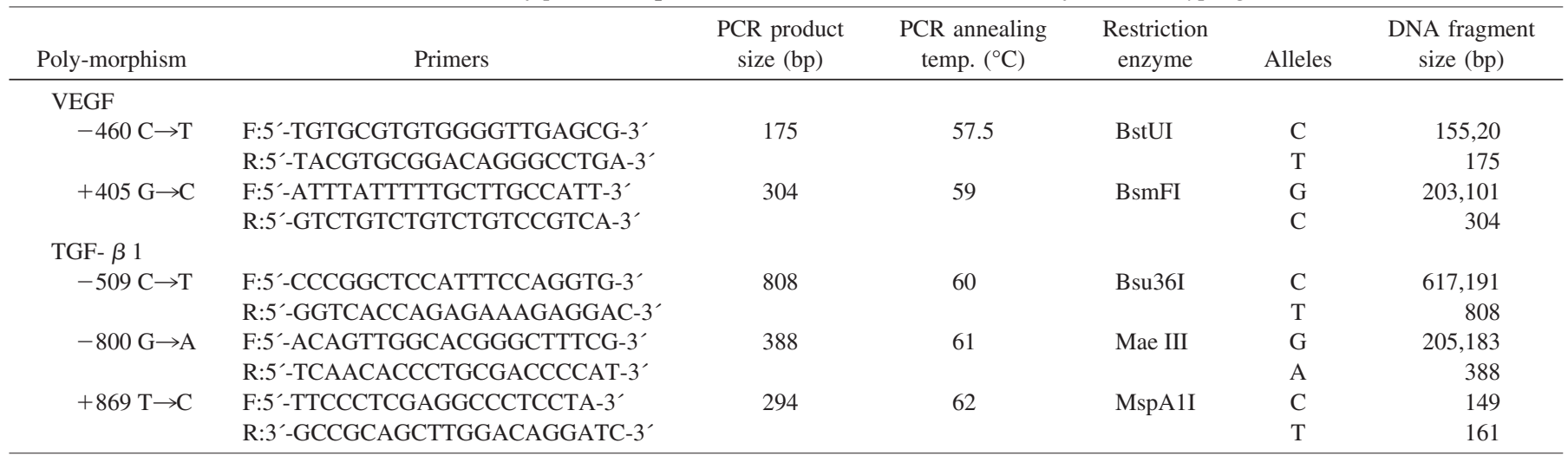


Table 2. Distributions of VEGF and TGF- $\beta 1$ genotypes

\begin{tabular}{|c|c|c|c|c|c|c|}
\hline Polymorphism & Controls & $\begin{array}{c}\text { UTI with/without } \\
\text { VUR }\end{array}$ & $\begin{array}{l}\text { UTI with } \\
\text { VUR }\end{array}$ & $\begin{array}{l}\text { UTI without } \\
\text { VUR }\end{array}$ & RPS & NS \\
\hline \multicolumn{7}{|l|}{ VEGF - 460} \\
\hline $\mathrm{TT}$ & $54.3(38)$ & $69.8(44)$ & $73.3(33)$ & $61.1(11)$ & $75(27)$ & $64(16)$ \\
\hline $\mathrm{CC}$ & $4.3(3)$ & $15.9(10)^{*}$ & $17.8(8)^{*}$ & $11.1(2)$ & $16.7(6)$ & $12(3)$ \\
\hline $\mathrm{T}: \mathrm{C}$ & $0.75: 0.25$ & $0.77: 0.23$ & $0.78: 0.22$ & $0.75: 0.25$ & $0.79: 0.21$ & $0.76: 0.24$ \\
\hline \multicolumn{7}{|l|}{+405} \\
\hline $\mathrm{CC}$ & $24.3(20)$ & $16.9(12)$ & $17.3(9)$ & $15.8(3)$ & $16.7(7)$ & $17.2(5)$ \\
\hline G:C & $0.52: 0.48$ & $0.57: 0.43$ & 0.59:0.41 & $0.53: 0.47$ & 0.60:0.40 & $0.53: 0.47$ \\
\hline \multicolumn{7}{|l|}{-509} \\
\hline $\mathrm{CC}$ & $8.7(7)$ & $34.6(27)^{*}$ & $35.1(20)^{*}$ & $33.3(7)^{*}$ & $32.6(15)$ & $37.5(12)$ \\
\hline $\mathrm{CT}$ & $50(40)$ & $41.0(32)$ & $35.1(20)$ & $57.1(12)$ & $34.8(16)$ & $50.0(16)$ \\
\hline $\mathrm{TT}$ & $41.3(33)$ & $24.4(19)^{*}$ & $29.8(17)$ & $9.5(2)^{*}$ & $32.6(15)$ & $12.5(4)$ \\
\hline $\mathrm{AA}$ & $0.0(0)$ & $0.0(0)$ & $0.0(0)$ & $0.0(0)$ & $0.0(0)$ & $0.0(0)$ \\
\hline G:A & $0.60: 0.40$ & $0.70: 0.30$ & $0.70: 0.30$ & $0.70: 0.30$ & $0.73: 0.27$ & $0.66: 0.34$ \\
\hline \multicolumn{7}{|l|}{+869} \\
\hline TT & $28.2(24)$ & $35.1(27)$ & 33.3 (19) & $40(8)$ & $35.4(17)$ & 34.5 (10) \\
\hline $\mathrm{TC}$ & $44.7(38)$ & $39.0(30)$ & $36.8(21)$ & $45(9)$ & $29.2(14)$ & $55.2(16)^{* *}$ \\
\hline $\mathrm{CC}$ & $27.1(23)$ & $25.9(20)$ & $29.8(17)$ & $15(3)$ & $35.4(17)$ & $10.3(3)^{* *}$ \\
\hline $\mathrm{T}: \mathrm{C}$ & $0.51: 0.49$ & $0.55: 0.45$ & $0.52: 0.48$ & $0.63: 0.47$ & $0.50: 0.50$ & $0.62: 0.38$ \\
\hline
\end{tabular}

Values are shown as \% (n), * UTI with/without VUR $v s$ control, UTI with VUR $v s$ control, UTI without VUR $v s$ control, $p<0.05, * *$ RPS $v s$ NS, $p<0.05$.

Separate analysis between the children with UTI and no VUR and the control group. Compared with the control group, the TGF- $\beta 1-509$ CC genotype was found to be significantly increased (control, 8.7; UTI without VUR, 33.3\%; $p=0.011$ ) and -509 TT genotype was decreased (control, 41.3; UTI without VUR, 9.5\%; $p=0.014$ ) in the children with UTI and no VUR. There were no significant differences in the frequencies of other genotypes between the children with UTI and no VUR and the controls.

\section{DISCUSSION}

This study showed a significant increase of VEGF -460 CC, TGF- $\beta 1-509$ CC, and -800 GG genotypes in Korean patients with UTI and/or VUR as compared with normal controls. Also, the TGF- $\beta 1+869$ CC genotype was more frequent in RPS subjects than in NS subjects. Our findings suggest that these VEGF and TGF- $\beta 1$ polymorphisms may influence the susceptibility of Korean children to UTI, VUR, or subsequent renal scarring.

A significant correlation has been observed between VEGF protein production and two polymorphisms $(-460 /+405)$ investigated in this study. The VEGF $\mathrm{G}+405 \mathrm{C}$ polymorphism was significantly correlated with VEGF production in vitro (13) and carriage of the $-460 \mathrm{C} / 405 \mathrm{G}$ polymorphisms increased basal promoter activity by $71 \%$ compared with the wild-type sequence (19). Two polymorphisms at positions + 405 and -460 the start of transcription have been implicated as candidate single nucleotide polymorphisms (SNP) in diseases with a putative angiogenic basis $(14,20)$.
In this study, we observed increased frequency of the VEGF -460 CC genotype in patients with UTI and/or VUR, compared with the controls. Interestingly, there was no difference in the distribution of -460 genotypes between patients with RPS and those with NS, and none of the +405 genotypes was found more frequently in the UTI and/or VUR group or in subjects with RPS.

There is emerging evidence that VEGF is a proinflammatory factor and induces migration and activation of monocytes through induction of adhesion molecules (21). Intracellular adhesion molecule (ICAM)-1 expression was increased in serum of children with acute pyelonephritis (22) and those with VUR (23). According to the developmental theory of VUR (24), ectopic ureteral budding results in defective vesicoureteral valve, resulting in VUR. Recent findings showed that ectopic budding occurs in angiotensin type II receptor (AT2) null mutant embryos (25). Angiotensin II has also been reported to regulate vascular endothelial growth factor (VEGF) synthesis at the initiation phase of translation of VEGF mRNA in proximal tubular epithelial cells (26). VEGF is expressed both in podocytes and in tubular epithelial cells and adjacent metanephric mesenchymal cells in the developing kidney (27) and dysregulation of VEGF leads to distinct congenital renal disease (28). Taken together, VEGF may be one of the multiple genes or one of the genetic modifiers of AT2 in the development of UTI and/or VUR, and the $-460 \mathrm{CC}$ genotype could be associated with this increased activity of VEGF.

In contrast, Chen et al. (29) revealed that the frequency of the $-406 \mathrm{~T}$ allele was increased in patients with calcium stone 
disease, suggesting that the pathogenesis of stone disease occurs via a VEGF-related signal transduction pathway. However, these authors did not clarify the association between this allelic frequency and VEGF expression.

Why, then, was there no correlation with the VEGF -460 polymorphism and RPS? A cohort study demonstrated an association of the $-460 \mathrm{C}$ allele with progression to chronic kidney disease stage 5, implying that $\mathrm{C}$ allele at -460 may form part of a complex haplotype associated with progressive renal disease (14). VEGF is known to modify the renal scarring process via a variety of mechanisms (30) and is secreted from tubular cells by hypoxic stimulation (31). Because severe $\mathrm{RN}$ reflects tubulointerstitial damage, there may be a decrease in the number of functional tubules that produce and secrete VEGF, implying that decreased urinary VEGF is a poor prognostic indicator in patients with severe RN (9). Our finding that there was no correlation between VEGF -460 polymorphism and renal scarring could be attributed to diverse VEGF expression resulting from different severities of renal parenchymal damage.

Although we did not examine urinary VEGF level in our present study, it is likely that VEGF -460 polymorphism may be involved in determining susceptibility to UTI and/or VUR, reflecting increased VEGF production in the kidney. However, there may exist other polymorphisms that influence VEGF expression which were not analyzed in this study. As for VEGF + 405 polymorphism, there are conflicting results as to whether elevated serum levels of VEGF are associated with $+405 \mathrm{G}$ allele or $\mathrm{C}$ allele $(13,20)$. It is also arguable whether serum is a suitable medium in which to measure VEGF, since platelets represent a large source of stored VEGF (32).

We also observed that TGF- $\beta 1$ polymorphisms were associated with susceptibility to UTI, VUR, or renal scarring. The TGF- $\beta 1-509$ polymorphism occurs within the promoter region, the -800 polymorphism within the consensus cAMPresistant binding protein half-site, and the -869 polymorphism in the signal peptide sequence that is cleaved from the TGF- $\beta 1$ precursor at codon 29 (26-28). Linkage disequilibrium has often been found between C-509T and G-800A (33) or C-509T and $\mathrm{T}+869 \mathrm{C}$ (34) polymorphisms. These polymorphisms have been reported to be associated with the transcriptional activity or the serum level of the gene, indicating predisposition to diseases $(15,33,35)$.

TGF- $\beta 1$ has been found in increased concentrations in the urine of children with UTI (36) and polymorphisms of other inflammatory mediators may be involved in determining the severity of RPS following UTI $(15,37)$. Hydrodynamic pressure mimicking VUR in vitro increased TGF- $\beta 1$ secretion from renal tubular epithelial cells, showing that hydrodynamic and mechanical stress caused by sterile VUR could induce secretion of TGF- $\beta 1$ from the ureteric bud cells, interfering with the induction of metanephric mesenchymal development (12). Data also exist suggesting that TGF- $\beta 1$ and angiotensin II regulate the expression of each other (38). All these findings support the hypothesis that TGF- $\beta 1$ may be an important factor in the pathogenesis of UTI, VUR and renal scarring.

In this study, the frequency of the $-509 \mathrm{CC}$ and $-800 \mathrm{GG}$ genotypes was significantly increased in patients with UTI and/or VUR, and there was no correlation with renal scarring. Conversely, the frequency of the +869 CC genotype was increased in patients with RPS compared with those with NS, but not in those with UTI and/or VUR.

T-509, G-800, and C+869 alleles have often been reported to be associated with serum or in vitro TGF- $\beta 1$ level, but contrasting results have been published $(15,33,35)$. Cotton $e t$ al. (15) showed an association between -800 GA genotype and low TGF- $\beta 1$ production in vitro, suggesting a protective role against RPS, but there was no association between -509 or +869 genotypes and protein production. On the other hand, Sato et al. (34) demonstrated that both patients with $\operatorname{IgA}$ nephropathy with $-509 \mathrm{CC}$ and those with $+869 \mathrm{CC}$ genotypes presented with heavy proteinuria and a higher score of mesangial cell proliferation, indicating the importance of proving the direct association between TGF- $\beta 1$ gene variation and its expression in local renal tissue. Recently, Farmaki et $a l$. (36) also observed significantly higher TGF- $\beta 1$ concentrations in the urine of children with normal DMSA scans than in those with abnormal DMSA scans. They observed that urinary TGF- $\beta 1$ is secreted for a very short time after the diagnosis of UTI, with a time-dependent decrease. Thus, the evidence to support a role for TGF- $\beta 1$ in RPS following UTI is conflicting $(15,36)$ and TGF- $\beta 1$ polymorphisms may be more important as risk factors for VUR and initial infection.

Since the majority of children with UTI also had VUR, it is difficult to sort out whether the polymorphisms correlate with risk of UTI or risk of VUR. A separate analysis of the children with UTI and no VUR would be helpful in this regard. However, this analysis was restricted to showing only the differences of TGF- $\beta 1$ C-509T polymorphisms. Low numbers of patients with UTI and no VUR may contribute to these varying results. It is also very difficult to determine the true associations of the polymorphisms because VUR and UTI are associated with each other. Further study with more participants is needed to verify and adequately explain our findings.

Interestingly, the majority of patients in our study were male, which differs from other studies. Most of patients were not extremely young, and there was no significant age difference among the groups. We cannot explain this, but it seems unlikely that this sex distribution would affect the results of these polymorphisms.

There are some limitations in explaining the correlation of these polymorphic variants with VEGF or TGF- $\beta 1$ level, since we did not measure protein concentrations. The relationship between genotypes and protein function could even be more complicated than it appears to be. There is also a possibility that these polymorphisms may be in linkage disequilibrium, which would affect the VEGF and TGF- $\beta 1$ activity in the pathogenesis of UTI, VUR, and RPS. Haplotype analysis could be more informative than the SNP. Many parameters such as different ethnic background or other genetic modifiers could potentially influence the results of genetic polymorphisms. Further prospective study with a long-term follow-up is needed to establish prognostic significance of these genetic polymorphisms in UTI and VUR, and subsequent renal scarring. 
In summary, VEGF and TGF- $\beta 1$ polymorphisms may have important roles in the pathogenesis or progression of UTI and VUR. The findings of this study imply that the VEGF T-460C and the TGF- $\beta 1 \mathrm{C}-509 \mathrm{~T}, \mathrm{G}-800 \mathrm{~A}$, and $\mathrm{T}+869 \mathrm{C}$ polymorphisms could be candidate genetic markers of development and progression of childhood UTI and VUR.

Acknowledgments. The authors thank M.S. Forbes for advice and assistance.

\section{REFERENCES}

1. Khalil A, Brauner A, Bakhiet M, Burman LG, Jaremko G, Wretlind B, Tullus K 1997 Cytokine gene expression during experimental Escherichia coli pyelonephritis in mice. J Urol 158:1576-1580

2. Hertting O, Khalil A, Jaremko G, Chromek M, Li YH, Bakhiet M, Bartfai T, Tullus K, Brauner A 2003 Enhanced chemokine response in experimental acute Escherichia coli pyelonephritis in IL-1beta-deficient mice. Clin Exp Immunol 131:225233

3. Mak RH, Kuo HJ 2003 Primary ureteral reflux: emerging insights from molecular and genetic studies. Curr Opin Pediatr 15:181-185

4. Khalil MS, El Nahas AM, Blakemore AI 2005 Transforming growth factor-beta1 SNPs: genetic and phenotypic correlations in progressive kidney insufficiency. Nephron Exp Nephrol 101:e31-e41

5. Yim HE, Jung MJ, Choi BM, Bae IS, Yoo KH, Hong YS, Kim SK 2004 Genetic polymorphism of the renin-angiotensin system on the development of primary vesicoureteral reflux. Am J Nephrol 24:178-187

6. Ferrara N, Chen H, Davis-Smyth T, Gerber HP, Nguyen TN, Peers D, Chisholm V Hillan KJ, Schwall RH 1998 Vascular endothelial growth factor is essential for corpus luteum angiogenesis. Nat Med 4:336-340

7. Shulman K, Rosen S, Tognazzi K, Manseau EJ, Brown LF 1996 Expression of vascular permeability factor (VPF/VEGF) is altered in many glomerular diseases. J Am Soc Nephrol 7:661-666

8. Konda R, Sato H, Sakai K, Sato M, Orikasa S, Kimura N 1999 Expression of platelet-derived endothelial cell growth factor and its potential role in up-regulation of angiogenesis in scarred kidneys secondary to urinary tract diseases. Am J Pathol 155:1587-1597

9. Konda R, Sato H, Sakai K, Abe Y, Fujioka T 2004 Urinary excretion of vascular endothelial growth factor is increased in children with reflux nephropathy. Nephron Clin Pract 98:C73-C78

10. Border WA, Noble NA 1994 Transforming growth factor beta in tissue fibrosis. N Engl J Med 331:1286-1292

11. MacRae Dell K, Hoffman BB, Leonard MB, Ziyadeh FN, Schulman SL 2000 Increased urinary transforming growth factor-beta (1) excretion in children with posterior urethral valves. Urology 56:311-314

12. Maruyama T, Hayashi Y, Nakane A, Sasaki S, Kohri K 2005 Intermittent pressureloading increases transforming growth factor-beta-1 secretion from renal tubular epithelial cells: in vitro vesicoureteral reflux model. Urol Int 75:150-158

13. Watson CJ, Webb NJ, Bottomley MJ, Brenchley PE 2000 Identification of polymorphisms within the vascular endothelial growth factor (VEGF) gene: correlation with variation in VEGF protein production. Cytokine 12:1232-1235

14. Summers AM, Coupes BM, Brennan MF, Ralph SA, Short CD, Brenchley PE 2005 VEGF-460 genotype plays an important role in progression to chronic kidney disease stage 5. Nephrol Dial Transplant 20:2427-2432

15. Cotton SA, Gbadegesin RA, Williams S, Brenchley PE, Webb NJ 2002 Role of TGF-beta1 in renal parenchymal scarring following childhood urinary tract infection. Kidney Int 61:61-67

16. Solari V, Owen D, Puri P 2005 Association of transforming growth factor-beta1 gene polymorphism with reflux nephropathy. J Urol 174:1609-1611
17. Syrris P, Carter ND, Metcalfe JC, Kemp PR, Grainger DJ, Kaski JC, Crossman DC, Francis SE, Gunn J, Jeffery S, Heathcote K 1998 Transforming growth factor-beta1 gene polymorphisms and coronary artery disease. Clin Sci (Lond) 95:659-667

18. Wood NA, Thomson SC, Smith RM, Bidwell JL 2000 Identification of human TGF-beta1 signal (leader) sequence polymorphisms by PCR-RFLP. J Immunol Methods 234:117-122

19. Stevens A, Soden J, Brenchley PE, Ralph S, Ray DW 2003 Haplotype analysis of the polymorphic human vascular endothelial growth factor gene promoter. Cancer Res 63:812-816

20. Awata T, Inoue K, Kurihara S, Ohkubo T, Watanabe M, Inukai I, Inoue I, Katayama S 2002 A common polymorphism in the 5'-untranslated region of the VEGF gene is associated with diabetic retinopathy in type 2 diabetes. Diabetes 51:1635-1639

21. Kim I, Moon SO, Kim SH, Kim HJ, Koh YS, Koh GY 2001 Vascular endothelial growth factor expression of intercellular adhesion molecule 1 (ICAM-1), vascular cell adhesion molecule 1 (VCAM-1), and E-selectin through nuclear factor-kappa B activation in endothelial cells. J Biol Chem 276:7614-7620

22. Gbadegesin RA, Cotton SA, Coupes BM, Awan A, Brenchley PE, Webb NJ 2002 Plasma and urine soluble adhesion molecule expression is increased during first documented acute pyelonephritis. Arch Dis Child 86:218-221

23. Miyakita H, Puri P, Surana R, Kobayashi H, Reen DJ 1995 Serum intracellular adhesion molecule (ICAM-1), a marker of renal scarring in infants with vesicoureteric reflux. Br J Urol 76:249-251

24. Mackie GG, Stephens FD 1975 Duplex kidneys: a correlation of renal dysplasia with position of the ureteral orifice. J Urol 114:274-280

25. Oshima K, Miyazaki Y, Brock JW 3rd Adams MC, Ichikawa I, Pope JC 4th 2001 Angiotensin type II receptor expression and ureteral budding. J Urol 166:1848-1852.

26. Feliers D, Duraisamy S, Barnes JL, Ghosh-Choudhury G, Kasinath BS 2005 Translational regulation of vascular endothelial growth factor expression in renal epithelial cells by angiotensin II. Am J Physiol Renal Physiol 288:F521-F529

27. Kitamoto Y, Tokunaga H, Tomita K 1997 Vascular endothelial growth factor is an essential molecule for mouse kidney development: glomerulogenesis and nephrogenesis. J Clin Invest 99:2351-2357

28. Eremina V, Sood M, Haigh J, Nagy A, Lajoie G, Ferrara N, Gerber HP, Kikkawa Y, Miner JH, Quaggin SE 2003 Glomerular-specific alterations of VEGF-A expression lead to distinct congenital and acquired renal diseases. J Clin Invest 111:707-716

29. Chen WC, Chen HY, Wu HC, Wu MC, Hsu CD, Tsai FJ 2003 Vascular endothelial growth factor gene polymorphism is associated with calcium oxalate stone disease. Urol Res 31:218-222

30. Kang DH, Hughes J, Mazzali M, Schreiner GF, Johnson RJ 2001 Impaired angiogenesis in the remnant kidney model (II): VEGF administration reduces renal fibrosis and stabilizes renal function. J Am Soc Nephrol 12:1448-1457

31. El Awad B, Kreft B, Wolber EM, Hellwig-Burgel T, Metzen E, Fandrey J, Jelkmann W 2000 Hypoxia and interleukin-1beta stimulate vascular endothelial growth factor production in human proximal tubular cells. Kidney Int 58:43-50

32. Webb NJ, Bottomley MJ, Watson CJ, Brenchley PE 1998 Vascular endothelial growth factor (VEGF) is released from platelets during blood clotting: implications for measurement of circulating VEGF levels in clinical disease. Clin Sci (Lond) 94:395-404

33. Grainger DJ, Heathcote K, Chiano M, Snieder H, Kemp PR, Metcalfe JC, Carter ND, Spector TD 1999 Genetic control of the circulating concentration of transforming growth factor type beta1. Hum Mol Genet 8:93-97

34. Sato F, Narita I, Goto S, Kondo D, Saito N, Ajiro J, Saga D, Ogawa A, Kadomura M, Akiyama F, Kanako Y, Ueno M, Sakatsume M, Gejyo F 2004 Transforming growth factor-betal gene polymorphism modifies the histological and clinical manifestations in Japanese patients with IgA nephropathy. Tissue Antigens 64:35-42

35. Yokota M, Ichihara S, Lin TL, Nakashima N, Yamada Y 2000 Association of $\mathrm{T} 29 \rightarrow \mathrm{C}$ polymorphism of the transforming growth factor-betal gene with genetic susceptibility to myocardial infarction in Japanese. Circulation 101:2783-2787

36. Farmaki E, Papachristou F, Winn RM, Karatzas N, Sotiriou J, Roilides E 2005 Transforming growth factor-betal in the urine of young children with urinary tract infection. Pediatr Nephrol 20:180-183

37. Gbadegesin RA, Cotton SA, Watson CJ, Brenchley PE, Webb NJ 2006 Association between ICAM-1 Gly-Arg polymorphism and renal parenchymal scarring following childhood urinary tract infection. Int J Immunogenet 33:49-53

38. Border WA, Noble NA 1998 Interactions of transforming growth factor-beta and angiotensin II in renal fibrosis. Hypertension 31:181-188 